УДК $378.147+792.075$

\author{
Юдов Микола Олександрович, \\ заслужений працівник культури України, доцент, \\ доцент кафедри режисури та майстерності актора \\ Київського національного університету \\ культури і мистецтв \\ ORCID: 0000-0002-9887-0834 \\ iudovmykola@gmail.com \\ Раденко Юлія Володимирівна, \\ заслужена артистка України, доцент кафедри \\ кіно-, телемистецтва факультету кіно \\ і телебачення Київського національного \\ університету культури і мистецтв \\ ORCID iD 0000-0002-8927-2103 \\ aktrisajuli1961@gmail.com
}

\title{
ПРОБЛЕМИ ІНДИВІДУАЛЬНОГО ПІДХОДУ В СИСТЕМІ ПІДГОТОВКИ РЕЖИСЕРІВ ДРАМАТИЧНОГО ТЕАТРУ В УМОВАХ ЗАОЧНОЇ ФОРМИ НАВЧАННЯ У ВНЗ
}

Мета роботи - дослідити проблемні аспекти процесу індивідуалізації навчальної роботи студентів і особливості її реалізації в системі особистісної професійної підготовки режисерів драматичного театру у вищих навчальних закладах у формі заочного навчання. Основу методології дослідження складає системний та аналітичний підходи, що дозволяє визначити особливості організації індивідуалізованої підготовки режисерів драматичного театру у формі заочного навчання як складової цілісного освітнього процесу. Наукова новизна роботи полягає у систематизації та узагальнені даного досвіду у контексті театральної педагогіки. Висновки. У підсумку зазначається, що індивідуальний підхід в системі особистісної підготовки режисерів драматичного театру на заочному відділення має свою специфіку. Практичний досвід роботи надає студенту заочного навчання значні переваги в засвоєнні навчальної інформації, дозволяючи отримані у ВНЗ знання безпосередньо пов'язувати з потребами професійної діяльності у театральному колективі. До того ж студент-практик більш вибірковий у своєму ставленні до навчальної інформації. Позитивну мотивацію в нього викликають ті знання, цінність яких він вбачає у практиці. Таким чином, важливою умовою підвищення професійної підготовки студентів заочної форми навчання $\epsilon$ розуміння і врахування викладачем переваг заочної освіти, зокрема забезпечення максимального зв'язку з практикою професійної діяльності здобувачів освіти. Цей зв'язок можна забезпечити шляхом індивідуалізації освіти студентів заочної форми навчання, необхідною і вагомою складовою якої є керована індивідуалізована самоосвіта.

Ключові слова: заочна освіта, режисер драматичного театру, індивідуальний підхід, особистісно орієнтована освіта, самоосвіта.

Юдов Николай Александрович, заслуженный работник культуры Украины, дочент, дочент кафедры режиссуры и мастерства акт раКиевского начионального университета культуры и искусств; Раденко Юлия Владимировна, заслуженная артистка Украины, дочент кафедры кино-, телеискусства факультета кино и телевидения Киевского национального университета культуры и искусств;

Проблемы индивидуального подхода в системе подготовки режиссеров драматического театра в условиях заочной формы обучения в ВУЗах

Цель статьи - исследовать проблемные аспекты процесса индивидуализации учебной работы студентов и особенности ее реализации в системе личностной профессиональной подготовки режиссеров драматического театра в высших учебных заведениях в форме заочного обучения. Основу методологии исследования составляет системный и аналитический подходы, что позволяет определить особенности в организации индивидуализированной подготовки режиссеров драматического театра в форме заочного обучения как составляющей целостного образовательного процесса. Научная новизна публикации заключается в систематизации и обобщении данного опыта в аспекте театральной педагогики. Выводы. В итоге отмечается, что индивидуальный подход в системе личностной подготовки режиссеров драматического театра на заочном отделение имеет свою специфику. Практический опыт работы дает студенту заочного обучения значительные преимущества в освоении учебной программы, позволяя полученные в ВУЗе знания непосредственно связывать с потребностями профессиональной деятельности в конкретном театральном коллективе. К тому же студент-практик более избирателен в своем отношении к учебной информации. Положительную мотивацию к освоению у него вызывают те знания, ценность которых он определяет на практике. Таким образом, важным условием повышения профессиональной подготовки студентов заочной формы обучения является понимание

СЮдов М. О., 2019

СРаденко Ю. В., 2019 
и учет преподавателем преимуществ заочного образования, в частности обеспечение максимальной связи с практикой профессиональной деятельности соискателей образования. Эту связь можно обеспечить путем индивидуализации образования студентов заочной формы обучения, необходимой и важной составляющей которой является управляемое индивидуализированое самообразование.

Ключевые слова: заочное образование, режиссер драматического театра, индивидуальный подход, личностно ориентированное образование, самообразование.

Yudov Mykola, Honored Worker of Culture of Ukraine, Associate Professor, Associate Professor at the directing and actor's skills chair of Kyiv National University of Culture and Arts; Radenko Yuliya, Honored Artist of Ukraine, Associate Professor of the Department of Film and Television Arts Faculty of Film and Television Kiev National Unive rsity of Culture and Arts

Problems of the individual approach in the preparation system of directors of drama theater at the parttime education in the University

The purpose of the article is to investigate the problematic aspects of the process of individualization of students' educational work and features of its implementation in the system of personal, professional preparation system of directors of drama theater in higher educational institutions in the form of correspondence education. The methodology basis is the systemic and analytical approaches, which makes it possible to identify features in the organization of individualized preparation of directors of dramatic theater in the form of correspondence education as part of a holistic educational process. The scientific novelty of the publication lies in the systematization and synthesis of this experience in the aspect of theatrical pedagogy. Conclusions. As a result, it is noted that the individual approach in the system of personal preparation of directors of drama theater in the correspondence department has its specifics. Practical work experience gives an extramural student a significant advantage in mastering the curriculum, allowing the knowledge gained at an institution of higher education to be directly associated with the needs of professional activity in a particular theater group. Besides, the student practitioner is more selective in his attitude to educational information. The knowledge causes the positive motivation to master him, the value of which he determines in practice. Thus, an important condition for enhancing the professional preparation of correspondence students is that the teacher understands and takes into account the advantages of correspondence education, in particular, ensuring maximum communication with the practice of professional activities of applicants. This relationship can be achieved by individualizing the education of part-time students, the necessary and essential component of which is managed individualized self-education.

Key words: distance education, director of drama theater, individual approach, personality-oriented education, self-education

Актуальність теми дослідження. Після прийняття Верховною Радою України в 2014 році «Закону про вищу освіту» в нашій країні відбувається активна його імплементація. Цей процес тісно пов'язаний з втіленням в життя нових принципів організації діяльності у вищих навчальних закладах. ВН3 отримали широкі права, що складають зміст їх автономії та самоврядування, у тому числі отримали право самостійно визначати форми навчання та організації освітнього процесу (Ст. 32. Принципи діяльності, основні права та обов’язки вищого навчального закладу Закону України «Про вищу освіту») [1].

Нинішній Закон України «Про вищу освіту» цілком корелюється із зарубіжними та вітчизняними тенденціями у розвитку освіти щодо іiі особистісної орієнтації, яка тісно взаємопов'язана 3 вирішенням питань індивідуалізації та самоосвіти. 3 суті особистісної освіти витікає необхідність саморозвитку, самонавчання, самовиховання студентів, які навчаються на заочному відділенні у ВНЗ, протягом набуття ними компетентності.

Аналіз останніх досліджень і публікацій. Обрана тема наукового дослідження - індивідуальний підхід у підготовці режисерів драматичного театру на заочному відділенні у ВН3 - зумовлена ii актуальністю. Адже на сьогодні практично відсутні наукові дослідження та аналітичні праці з обраної проблематики, а в опублікованих у різний час матеріалах і статтях подається досить фрагментарна інформація $[3,6,8,9,10,11,12]$, яка в нинішніх умовах стрімкої трансформації суспільства швидко втрачає свою актуальність.

На необхідність комплексного підходу в індивідуалізації процесу навчання звертали увагу багато хто з педагогів. Розробку цих питань ми знаходимо у роботах Я.А. Коменського, Дж. Локка, Ж.-Ж. Руссо, а також А. Дістервега, К. Ушинського, Л. Толстого та інших. При всій різновекторності суджень щодо врахування природних особливостей розвитку особи, всі вони сходяться в одному завжди необхідно уважно вивчати особистість, знати ії особливі риси і спиратися на них у процесі навчання. Корисні ідеї з цього питання знаходимо у працях П. Блонського, С. Шацького, А. Макаренка, В. Сухомлинського, Н. Крупської та інших теоретиків і практиків навчального процесу.

Необхідність вивчення індивідуального підходу в процесі підготовки режисерів драматичного театру зумовлена тією обставиною, що педагогічний вплив на особистість, зокрема творчу, має 
проходити із врахуванням іiі індивідуальних особливостей, без чого неможливий плідний навчальновиховний процес. Студент, зокрема, студент заочної форми навчання майбутній режисер, передусім, - творча особистість, яка не тільки піддається педагогічному впливу в навчальному закладі, а й переживає свої творчо-психологічні етапи розвитку, які супроводжуються проблемами i конфліктами. Отже, з вище зазначеного можна зробити висновок: питання щодо вивчення та врахування індивідуальних характеристик особистості в цілому і зокрема студентів - майбутніх режисерів, стоїть одним із провідних затребуваних аспектів процесу формування творчої, всебічно розвиненої та освіченої людини.

Мета даної роботи дослідити проблемні аспекти процесу індивідуалізації навчальної роботи студентів і особливості їі реалізації в системі особистісної професійної підготовки режисерів драматичного театру на заочній формі навчання у вищому навчальному закладі.

Виклад основного матеріалу. Заочна освіта - одна 3 форм безвідривної від виробництва освіти, що отримала поширення в системі вищої освіти. Студенти відвідують інтенсивний курс настановних лекцій, а процес засвоєння навчального матеріалу спрямовується викладачем шляхом надання завдань для самостійної роботи та контролюється шляхом перевірки самостійно виконаних робіт. Якість підготовки спеціалістів без відриву від виробництва залежить від низки факторів. I в першу чергу від того, на скільки повною мірою використовуються переваги заочної освіти, враховуючи іiі складності, чи створюються умови для досягнення оптимальних результатів. Переважна більшість педагогічних невдач при цій формі навчання виникає із-за нерозуміння специфічності заочного навчання та із-за прагнення максимально наблизити його до очного.

Особливість заочного навчання полягає не тільки в тому, що навчальними планами передбачається значне зменшення аудиторних занять в порівнянні зі стаціонарним (практично в половину), майже піврічні перерви у навчанні, серйозне завантаження студентів виробничими, громадськими, сімейними справами. Такі атрибути заочної освіти можна віднести до категорії проблемних. У системі екстернатної та дистанційної освіти ці питання стоять ще гостріше. Однак, до позитивних характеристик, що сприяють підвищенню продуктивності заочного навчального процесу, можна віднести, зокрема, що студенти достатньо аргументовано вмотивовані необхідністю підвищення загальноосвітнього та професійного рівня. В наслідок цього їхнє ставлення до навчання, зокрема, до виконання самостійної роботи як вагомої складової освітнього процесу, більш усвідомлене в порівнянні зі студентами стаціонару.

Безумовною складовою особистісно орієнтованої освіти $є$ індивідуальний підхід у роботі викладача зі студентом. Концептуально індивідуальний підхід базується на розумінні того, що індивідуальність людини полягає в іï осібних характеристиках. Виникнення індивідуальних особливостей (відмінностей) пов'язано з тим, що кожен індивід проходить свій шлях розвитку, набуваючи при цьому різних типологічних особливостей вищої нервової системи. Останні впливають на своєрідність відчування, сприйняття, мислення, пам'яті, уяви, особливості інтересів, нахилів, здібностей, темпераменту, характеру особистості. Ці індивідуальні особливості впливають на розвиток індивіду.

Сучасна вітчизняна педагогіка стоїть на позиції того, що індивідуальний підхід як важливий принцип є вагомою складовою системи сучасної освіти. Адже врахування індивідуальних здібностей полягає не у підпорядкуванні цілей $\mathrm{i}$ основного змісту навчання окремому студенту, а в індивідуальному підборі форм і методів навчання з тим, щоб забезпечити запроектовані результати навчання - сукупність знань, умінь, навичок, інших компетентностей, набутих особою в процесі навчання за певною освітньо-професійною, освітньо-науковою програмою, які можна ідентифікувати, кількісно оцінити та виміряти.

Основне положення принципу індивідуалізації базується на діалектиці загального і особливого, виняткового, типового та індивідуального, абстрактного і конкретного в пізнанні і розвитку людини. Як вважає C.I. Змєєв [4, с. 26], у відповідності до цього принципу кожен здобувач освіти разом із педагогом, а в деяких випадках і колективно з іншими здобувачами створює індивідуальну програму навчання, зорієнтовану на конкретні освітні потреби і цілі навчання і таку, що враховує досвід, рівень підготовки, психофізіологічні, когнітивні особливості здобувача.

На наш погляд, сьогодні гостро відчувається необхідність застосування принципу індивідуалізації при організації педагогічного спілкування зі студентами заочної форми навчання у ВН3. Деіндивідуалізована педагогічна взаємодія - взаємодія фронтальна, не орієнтована на індивідуальність студента, на специфічність його інтересів і здібностей, - вона спирається на так звані соціальні норми оцінювання, коли те чи інше досягнення дорослого здобувача освіти порівнюється не 3 його ж попередніми досягненнями, 3 досягненнями інших студентів. Така 
деіндевідуалізована взаємодія байдужа до різносторонніх інтересів i професійних досягнень студентів заочної форми навчання, до їх самостійної творчості, не залежно від сфер її прояву.

В сучасних умовах навчання звернення до проблеми індивідуальних особливостей студентів $\mathrm{i}$ організація індивідуального підходу набуває все більшого значення. Індивідуальні особливості можуть позитивно впливати на процес навчання, бути нейтральними або негативно позначатися на навчальній діяльності студента. Ступінь впливу індивідуальних особливостей на процес навчання визначає необхідність індивідуального підходу.

В дидактиці проблема індивідуального підходу в навчанні носить творчий характер. Необхідність реалізації індивідуального підходу пов'язана, в першу чергу: 1) з об'єктивно існуючими протиріччями між загальними для всіх студентів цілями, змістом навчання й індивідуальними можливостями кожного здобувача освіти; 2) між фронтальним викладенням лекційного матеріалу викладачем та індивідуальними особливостями сприйняття, пам'яті, інтересів, що визначають індивідуальний характер навчального матеріалу конкретним студентом. Таким чином, шляхом індивідуального підходу педагог може «відкрити» в комусь зі студентів, те, що раніше не проявлялось - присутність особливих здібностей, що потребують розвитку шляхом індивідуального підходу в навчальному процесі. Знання індивідуальних здібностей - необхідна умова реалізації індивідуального підходу [7]. Але варто зазначити, що індивідуальний підхід до здобувача освіти може бути успішним лише за умови активної діяльності самого студента. Без внутрішніх духовних зусиль студента ВНЗу, без його вмотивованого бажання стати професійно компетентним неможливе здобуття високої якості освіти.

Застосування концепції особистісної освіти з такою їі вагомою складовою як індивідуальний підхід особливо важливе у набутті здобувачами освіти компетенції за творчими спеціальностями, зокрема, в процесі підготовки режисерів театрального мистецтва в умовах заочної форми навчання у BH3.

Питання індивідуалізації навчання є надзвичайно відповідальним для педагога, оскільки в момент зарахування студента на режисерський курс вирішується не лише його подальша доля, але й перспектива розвитку театрального мистецтва загалом. Попереднє дослідження індивідуальних особливостей абітурієнта заочної форми навчання проводиться підчас вступних випробувань, де майбутні студенти демонструють свої творчі й професійні навички та здібності, за якими можна скласти індивідуальну картину кожного. Результати такого дослідження в подальшому стають основою освітнього процесу, де педагог індивідуалізуватиме процес фахової підготовки студента заочної форми навчання - майбутнього режисера драматичного театру.

Стилістичні особливості режисера як творця мають чимале значення в театральному мистецтві, а вони безпосередньо залежать від його особистісних якостей - громадянської позиції, творчої активності, самостійності мислення тощо. Завдання педагога виявити ці особистісні якості i спонукати студента самостійно транслювати їх у мистецтво, навчити формулювати те, що турбує його в житті, театральними засобами на сцені. Для цього необхідно створити відповідні умови навчання, важливе місце в яких займає індивідуалізація самостійного оволодіння знаннями i навичками.

Відмінною рисою індивідуалізованої самостійної роботи студентів заочної форми навчання $є$ те, що вона переважно здійснюється у практичній площині їхньої професійної діяльності. Саме на практиці надається можливість проявити творчу активність, перевірити та закріпити здобуті теоретичні знання в реальних умовах театральної діяльності. Студент може самостійно обрати літературний матеріал або, навіть, створити його (написати п’єсу, сценарій, інсценізацію) і поставити його на сцені, запропонувавши свій доробок глядачеві в умовах реальної театральної діяльності. Такий досвід активізує діяльність студента заочної форми навчання, підвищує його відповідальність за обрану справу, спонукає до вирішення творчих завдань.

До форм самостійної роботи здобувачів театральної режисерської освіти, які навчаються на заочному відділенні у ВН3, належать різноманітні практичні завдання, зміст яких визначається, перш за все, завданнями навчального курсу, навчальної дисципліни і можливостями колективу, де працює здобувач. Крім того, в змісті запропонованих самостійних завдань обов'язково має враховуватись освітній рівень підготовки студента заочної форми навчання (часто майбутні режисери заочної форми навчання мають вже акторську освіту та акторський і режисерський досвід роботи), його інтелектуальний розвиток, індивідуально-психологічні особливості, ступінь професійної активності, творчі здібності, духовні інтереси і потреби, оскільки самостійна робота завжди носить яскраво індивідуальний характер. Врахування всіх цих особливостей дозволяє навчити студентів знаходити наукову і прикладну інформацію, вибудовуючи іiї в струнку логічну систему; творчо застосовувати 
набуті знання для оволодіння новими, для вирішення будь-яких практичних завдань; аналізувати, спостерігати, узагальнювати і систематизовувати факти і події; прогнозувати появу нових напрямків, тенденцій в театральному мистецтві.

3 метою попереднього діагностування індивідуальних особливостей студента-режисера необхідно на перших стадіях навчання глибоко вивчати його індивідуально-професійні якості, до яких належать: мотивація вибору в здобутті професії режисера, пізнавальні інтереси; відповідність спрямованості індивідуально-особистісних та режисерських якостей і здібностей вимогам обраної професії; початковий рівень набутих знань (навченості), успішності студентів-першокурсників: програмні та позапрограмні знання і навички; передумови до навчання (ступінь здатності до навчання): загальні розумові дані та спеціальні здібності; здібності до творчості.

Види мотивації при виборі режисерської професії в залежності від аргументів та вподобань студента можна структурувати наступним чином:

1. Особистісна мотивація - обумовлена психологічними характеристиками особи студентарежисера. До цієї групи варто віднести наступні обгрунтування: самоактуалізація, реалізація здібностей, самоствердження, естетичну насолоду, прагнення відчути «страждання та радощі» творчості, розрядку емоційної напруги, «звільнення» власної особистості шляхом мистецтва.

2. Соціальна мотивація - залежить від світосприйняття, від світогляду студента, від прагнення роботи з людьми і задля людей. До цієї групи належать наступні аргументи: пізнання нового, інтерес до світу, духовне спілкування з людьми, прагнення до самовдосконалення, вдосконалення життя, служіння людям, полегшення людського існування, створення для «свята душі», вплив на людей, розкриття власного бачення світу, донесення свого розуміння життя, пошук істини людського існування, прагнення до розкриття причин недосконалості людини і оточуючої дійсності.

3. Специфічно-професійна мотивація пов'язана 3 уявленнями студента про особливості театрального мистецтва, завдань на різних етапах навчального процесу та усвідомленням необхідних режисерських якостей для їх виконання. 3 обраних мотивів до даної групи потрапили: дієве створення творчої атмосфери в театрі, на сцені та прагнення виявити і вирішити моральні проблеми.

Визначення приналежності студента до відповідної групи базової підготовки сприяє оптимізації організації самостійної та індивідуальної роботи як самого студента, так і викладача.

Наукова новизна роботи полягає у систематизації та узагальнені досвіду організації індивідуалізованої підготовки режисерів драматичного театру у формі заочного навчання у контексті мистецької освіти та театральної

Висновки. Підсумовуючи можна зазначити, що індивідуальний підхід в системі особистісної підготовки режисерів драматичного театру на заочному відділення має свою специфіку. Практичний досвід роботи надає студенту заочного навчання значні переваги в засвоєнні навчальної інформації, дозволяючи отримані у ВНЗ знання безпосередньо пов'язувати з потребами професійної діяльності у театральному колективі. До того ж студент-практик більш вибірковий у своєму ставленні до навчальної інформації. Позитивну мотивацію в нього викликають ті знання, цінність яких він вбачає у практиці. Таким чином, важливою умовою підвищення професійної підготовки студентів заочної форми навчання $\epsilon$ розуміння і врахування викладачем переваг заочної освіти, зокрема забезпечення максимального зв'язку з практикою професійної діяльності здобувачів освіти. Цей зв'язок можна забезпечити шляхом індивідуалізації освіти студентів заочної форми навчання, необхідною і вагомою складовою якої є керована індивідуалізована самоосвіта.

Наразі українська освітня спільнота готується до активного впровадження у практику концепції дуальної освіти, запропонованої Міністром освіти і науки України Лілією Гриневич [2], - особливої форми здобуття освіти, передбачає попередньо узгоджене поєднання паралельного навчання осіб у закладах освіти із навчанням на робочих місцях, - наприклад, у театрально-видовищних закладах культури - 3 метою набуття відповідної кваліфікації - наприклад, режисерської. На даному етапі ВУЗи лише розпочинають осмислювати та планувати впровадження нового для України освітнього підходу, а науковці - аналізувати можливості його запровадження та прогнозувати наслідки [5]. Враховуючи спільні риси концепцій індивідуалізованої театральної режисерської освіти 3 відривом від виробництва та дуальної ऑiі форми без відриву від виробництва, запропонований аналіз проблемних аспектів освітнього процесу безумовно потребуватиме подальших наукових розвідок.

\section{Jimepamypa}

1. Про вищу освіту: Закон України від 01.07.2014 р. № 1556-VII. Вiдомості Верховної Ради України. 2014. № 37-38. Ст. 2004 
2. Гриневич Л. Привабити студентів та зупинити ї відтік можна лише якістю вищої освіти, яка зростає. Міністерство освіти і науки України [Офіційний сайт]. URL: https:/mon.gov.ua/ua/news/ liliya-grinevich-privabitistudentiv-ta-zupiniti-yih-vidtik-mozhna-lishe yakistyu-vishoyi-osviti-yaka-zrostaye (дата звернення : 21.06.2019)

3. Диба О.П., Тадля О.М. Компетентнісно-орієнтовані завдання в системі вищої освіти у сфері культури і мистецтв. Актуальні питання культурології: альманах наукового товариства «Афіна» кафедри культурології та музеєзнавства. 2018. Вип. 18. С. 46-52.

4. Змеев С.И. Технология обучения взрослых. Москва : Академия, 2002. 128 с.

5. Петрова I. В. Професійна підготовка івент-менеджерів у контексті дуальної форми здобугтя освіти. Вісник Київського наиіонального університету культури і мистеитв. Серія: Менеджмент соиіокультурної діяльності. 2019. №1. C. 82-104. DOI: https://doi.org/10.31866/2616-7573.1.2019.170657

6. Поцулко О.А. Дистанційна освіта в Україні. Наукова скарбниия освіти Донеччини: наук.-метод. журн. 2009. № 1. C. 24-28.

7. Сергєєв С.М., Рощупкін А.О. Урахування індивідуальних особливостей студентів у навчанні та вихованні. Актуальні проблеми навчання та виховання людей з особливими потребами. 2015. № 12(14). C. 182-194. URL: http://ap.uu.edu.ua/article/14 (дата звернення 18.06.2019)

8. Снеговая С.Н., Македонская Л.А. Тенденции развития дистанционного образования в Украине. Вісник Бердянського університету менеджменту і бізнесу. 2011. №1(13). С. 84-87.

9. Степаненко С. Про трансформацію системи заочної освіти в умовах інтеграції в європейський освітній простір. Вища школа. 2007. № 2. С. 31-37.

10. Стрельніков В.Ю., Брітченко І. Г. Сучасні технології навчання у вищій школі: модульний посібник для слухачів авторських курсів підвищення кваліфікації викладачів Міжгалузевого інститугу підвищення кваліфікації та перепідготовки спеціалістів (МІПК) ПУЕТ. Полтава : Полтавський університет економіки і торгівлі. 2013. 309 с.

11. Шуневич Б. Дистанційна освіта: теорії індустріалізації викладання. Педагогіка $і$ психологія професійної освіти. 2002. № 5. С. 45-50.

12. Яценко Г. Комунікативна сугність дистанційного навчання: постановка проблеми. Вища освіта України. 2007. № 3. C. 70-74.

\section{References}

1. Law of Ukraine on higher education from July 1 2014, № 1556-VII. (2014, September 19). Vidomosti Verkhovnoi Rady Ukrainy, 37-38, P. 2004 [in Ukrainian].

2. Hrynevych, L. (28.01.2018) It is only possible to increase the quality of higher education that can attract students and stop their outflow. Ministry of Education and Science of Ukraine [Official site]. Retrieved from: https://mon.gov.ua/ua/news/ liliya-grinevich-privabiti-studentiv-ta-zupiniti-yih-vidtik-mozhna-lishe yakistyu-vishoyi-osviti-yaka-zrostaye

3. Dyba, O.P. \& Tadlia, O.M. (2018). Competent-oriented challenges in the system of higher education in the sphere of culture and arts. Aktualni pytannia kulturolohii,18, 46-52 [in Ukrainian].

4. Zmeev, S.I. (2002). Technology learning Adults. Moscow: Akademiia [in Russian].

5. Petrova I. V. (2019). Professional training of event-managers in the context of dual form of acquiring education. Visnyk Kyivskoho natsionalnoho universytetu kultury i mystetstv. Seriia: Menedzhment sotsiokulturnoi diialnosti, 1. DOI: https://doi.org/10.31866/2616-7573.1.2019.170657

6. Potsulko, O.A. (2009). Distance education in Ukraine. Naukova skarbnytsia osvity Donechchyny, 1, 24-28 [in Ukrainian].

7. Serhieiev, S.M. \& Roshchupkin, A.O. (2015). Taking into account the individual characteristics of students' learning and education. Aktualni problemy navchannia ta vykhovannia liudei $\mathrm{z}$ osoblyvymy potrebamy. Retrieved from: http://ap.uu.edu.ua/article/14

8. Snegovaia, S.N. \& Makedonskaia, L.A. (2011). Trends in the development of distance education in Ukraine. Visnyk Berdianskoho universytetu menedzhmentu i biznesu, 1(13), 84-87 [in Russian].

9. Stepanenko, S. (2007). On the transformation of the system of correspondence education in the conditions of integration into the European educational space. Vyshcha shkola, 2, 31-37 [in Ukrainian].

10. Strelnikov, V.Iu. \& Britchenko, I. H. (2013). Modern technologies of teaching in high school. Poltava: Poltavskyi universytet ekonomiky i torhivli [in Ukrainian].

11. Shunevych, B. (2002). Distant education: theorys industrialization of teaching. Pedahohika i psykholohiia profesiinoi osvity, 5, 45-50 [in Ukrainian].

12. Iatsenko, H. (2007). Communicative essence of distance learning: problem statement. Vyshcha osvita Ukrainy, 3, 7074 [in Ukrainian]. 